Вісник Дніпропетровського університету. Серія: геологія, географія. 2016. 24 (1), 139-143.

Vìsnik Dnìpropetrovs'kogo unìversitetu. Serìa geologîa, geographìâ

Dnipropetrovsk University Bulletin. Series geology, geography. 2016, 24 (1), 139-143.

doi: $10.15421 / 111621$

http://geology-dnu.dp.ua

УДК 502. 91:55(477)

Перспективи створення мережі геопарків в Україні

\title{
В. В. Фундова
}

Дніпропетровський національний університет імені Олеся Гончара, Дніпропетровськ, Україна, e-mail: vfundovai@gmail.com

Більшість найцікавіших і найвідоміших місць на Землі пов'язана з різноманітними геолого-геоморфологічними утворами. Часто люди оселялися безпосередньо в таких місцях чи неподалік, використовували їх для оборони або проведення культових обрядів. Із часом змінювалися значення та функції таких місць - вони стали важливими для вивчення історії Землі, демонстрування різних геолого-геоморфологічних процесів та утворених ними форм рельєфу, а також набули значення як туристичні об'скти місцевості. Одночасно з посиленням інтересу до об'сктів геоспадщини та збільшення кількості бажаючих їх відвідати постала проблема їх збереження і раціонального використання, а також зросла необхідність подальшого вивчення цих об'сктів. Тому почали створювати геологічні парки. На теренах України також с багата та різноманітна геологічна спадщина та розвинута мережа природних ландшафтних парків, але саме питання створення геологічних парків постає дуже гостро. Мета наукової праці - обгрунтування необхідності створення геопарків на території України. Проведено аналіз та узагальнення роботи, яка вже здійснена на шляху до збереження геологічної спадщини. Виділено низку головних проблем на сьогодні, що постають перед ученими-геологами та потребують швидкого вирішення. Також у статті наведено короткий огляд геологічних об'сктів, найбільш перспективних для створення на їх територіях геологічних парків.

Ключові слова: геологічні пам'ятки (геосайти), геологічні парки (геопарки), геологічна спадщина, природно-заповідний фонд

\section{Prospects of creating of network geoparks in Ukraine}

\section{V. Fundova \\ Oles Honchar Dnipropetrovsk National University, Dnipropetrovsk, Ukraine, e-mail: vfundovai@gmail.com}

Majority of the most interesting and famous places in the world associated with various geological and geomorphological formations. Most people settled directly at or near such places, use them for defense or hold religious ceremonies. Over time the value and functions of such places has changed. They have become important for the study of the Earth's history, demonstrating various geological and geomorphological processes and resulting forms of relief. They also gained importance as tourist sites terrain. People were more interested in objects of the geological heritage and the number of people willing to visit them was more. The problem was their conservation and rational use, and need for further study of these objects increased. So people have been started creating geological parks. The territory of Ukraine also has a rich and varied geological heritage and the development of network natural landscape parks, but the question of creation of geological parks is very serious. The purpose of research is to rationale the need for geological parks in Ukraine. The analysis and generalization of work was conducted, which has already been accomplished on the way to the conservation of geological heritage. Several major problems highlighted as of today, with which geologists have encountered and which require quick solution. Also, a brief overview of geological objects was introduced at work. These objects are the most promising for the creation in their territories geological parks. Namely, it is geological objects Eagle's Nest, Podil'ski Tovtry, Bug Gard, outcrop Stylske, Stone Tombs (Kamenny Mogile), Vysachky' salt dome, glaciotectonic mountain Piviha in Poltava region, basalt columns «Ivanova Valley», Zacharovana Valley (Smerecov a Stone), Kanevsk glaciotectonic mountains.

Key words: geological monuments (geosites), geological parks (geoparks), geological heritage, Nature Reserve Land

Вступ. Геопарки - це переважно великоплощинні природоохоронні території, які охоплюють місцевості 3 унікальними демонстраційними властивостями фрагментів геологічної еволюції Землі та спрямовані на їх широке наукове, освітнє та традиційно-господарське використання. Геологічні пам'ятки, як найважливіші складові геопарків, слугують місцем першого знайом- ства людей з різноманітними аспектами природного світу, а також об'єктом туризму.

Актуальність даної теми безперечно стосується й України. Адже територія України теж має надзвичайно багато різноманітних, а подекуди унікальних об'єктів, вартих уваги всього світу. Її історія багата на геологічні події, а сучасне геологічне середови- 
ще цікаве великою різноманітністю, а це важливий аргумент для створення геологічних парків на ㄲi території.

Матеріали та методи вивчення. В Україні вже тривалий час ведуться розмови щодо створення геопарків, про що свідчать численні наукові статті 3 проблем охорони та вивчення геооб'єктів. Великий внесок у справу виявлення та збереження геологічної спадщини робить українська спілка ProGEO. Одним iз найважливіших заходів необхідності збереження об' єктів геологічної спадщини в нашій країні стало проведення V Міжнародного симпозіуму ProGEO (Київ, Кам'янець-Подільський) у 2006 році. Державна геологічна служба організувала вивчення геологічних пам'яток природи України, результатом чого стали не тільки звіти про виконані роботи, а й підготовка до видання двомовного чотиритомника «Геологічні пам'ятки України» та видання перших двох томів (західні регіони України та Український щит) (Bezvynniy, Bileckij, Bobrov, 2006).

Вищі навчальні заклади прагнуть дати якомога ширшу базу знань, а також залучати активну, небайдужу молодь до проблем охорони пам'яток природи, для чого й включають до геологічних практик відвідування студентами геоспадщини. Так, у 2014 році Дніпропетровський національний університет забезпечив своїм студентам практику на основі геотуристичного шляху, створеного в рамках проекту «Гео-Карпати». Він пролягав по карпатських територіях Підкарпатського воєводства на території Польщі та Львівської області в Україні. Отож під час навчальної практики студенти не тільки закріплять пройдений матеріал, а й отримають нові знання. У таких організованих виїздах, де можна все побачити на власні очі та самостійно вивчити, виникає більший інтерес до геологічних об' єктів, їх подальшого дослідження та захисту.

Також із 2012 року до програми навчання студентів геологічного напрямку Дніпропетровського національного університету імені Олеся Гончара включено новий курс «Моніторинг об' єктів геологічної спадщини» (Manyuk, 2014). Важлива частина курсу - ознайомлення та аналіз нормативно-законодавчої бази України відносно об'єктів природно-заповідного фонду в цілому і геологічної спадщини зокрема. Розглядається порядок створення та прийняття території та об'єктів природно-заповідного фонду. До курсу також входить більш детальний огляд геологічних пам' яток України. Досліджується проблема створення та розвитку міжнародних геопарків, у рамках якої оцінюються перспективи геопарків, та встановлення об'єктів першочергового значення. Навчальний курс приділяє увагу й туристич- ному аспекту використання пам'яток з метою їх популяризації та охорони. Курс передбачає й практичну частину: індивідуальна робота зі складання опису конкретних геосайтів України, де кожен студент також додає власні пропозиції щодо більшої популяризації та більш ретельного збереження того чи іншого об'єкта. Такий курс - позитивний крок у напрямку залучення ак-тивної молоді до сучасних проблем захисту геологічних об'єктів та проблем створення геопарків на теренах України.

Цілеспрямоване вивчення та облік геологічних пам'яток - порівняно новий напрям геологічних досліджень. Але в Україні давно ведеться активна діяльність 3 вивчення та збереження геологічної спадщини, що дає свої плоди. Сьогодні на порядку денному стоїть питання обгрунтування і створення в Україні геопарків та включення їх до Європейської мережі геопарків (Ivchenko,1998).

Так, одним з яскравих прикладів такої діяльності є створення комплексу унікальних об' єктів геологічної спадщини Криворізького залізорудного басейну, якому можна дати за однойменним геосайтом загальну назву «Орлине гніздо». Ерозія річок Саксагань та Інгулець розкрила фрагменти одного $з$ найбільших у світі родовища залізних руд, де можна спостерігати прояви розривної і складчастої тектоніки, виходи на поверхню багатих залізних руд, джеспілітів, різноманітних сланців, амфіболітів, гранітів, конгломератів, білих безрудних кварцитів, мармуру та інших порід. Власне комплекс складається 312 геологічних об'єктів, 10 я яких входять до реєстру природно-заповідного фонду України (Manyuk, 2008).

Також варто згадати геоспадщину Миколаївщини, а саме землі національного природного парку «Бузький Гард», які є унікальними та максимально інформативними в плані поєднання живої та неживої природи степової частини України. На II Міжнародній науково-практичній конференції, що відбулася 2011 року в м. Камянець-Подільський, науковці внесли пропозиції щодо цієї території та створення першого геопарку в Україні саме на цих землях (Golturenko, Manyuk, Artamonov, 2011).

Ще один унікальний природний об'єкт - це Подільські Товтри, що зараз стоять під загрозою зникнення. Сучасний стан надрокористування на вказаній території набув таких масштабів, що екологічна ситуація з неблагополучної переросте в загрозливу. Прогресуюче та ніким не контрольоване використання надр Товтрового пасма спричинює збільшення кількості кар'єрів та зростання масштабів видобутку сировини, що, звісно, не дасть ніякого позитивного впливу в майбутньому. Як стверджують учені, одним із найдоцільніших варіантів вирішення 
проблеми стане створення на згаданій території геологічного парку (Kaplun, Chebolda, 2008). Адже такий унікальний геологічний об'єкт, що не має аналогів та зараз стоїть під загрозою зруйнування, дає підстави щодо доцільності створення на всій території Подільських Товтр геопарку. Як відомо, Товтрове пасмо - це кораловий прибережний бар'єрний риф, що сформувався у теплому міоценовому морі. В основі Товтр лежать відклади середньоміоценової середземноморської і верхньоміоценової сарматської епох, та, відповідно, двох типів переважаючих рифотвірних порід: літотамнієвих водоростей i більш молодших моховатково-серпулових утворень (Korolyuk, 1952). Уперше правильно пояснив геологічну природу Товтр, указавши на їх органічне походження, російський геолог М. Барбот-де-Марні (1872). Геологічне вивчення Подільських Товтр ведеться й досі.

Питання створення геопарків в Україні вже активно обговорюють у наукових колах та природоохоронних організаціях. Територій для створення й функціонування геопарків вистачає. Однак у нашій країні існує низка певних проблем, пов' язаних з охороною, популяризацією та використанням геологічної спадщини.

1. Недосконала законодавча база. Так, недостатній контроль за виконанням Закону "Про природнозаповідний фонд України" в низці випадків призводить не тільки до пошкоджень, а й до знищення унікальних геологічних об'єктів. Також проблема полягає в забезпеченні задовільного стану геологічної спадщини, адже більшість зовсім не охороняється в тій мірі, якої вона потребує. Слід зазначити, що низка геологічних об'єктів не підлягає жодній 3 існуючих охоронних форм в Україні.

2. Недосконала інфраструктура туризму.

3. Нераціональне використання. Незважаючи на те, що той чи інший об'єкт є геологічною спадщиною, дуже часто трапляються випадки надмірного використання як самих окремих об'єктів, так і територіальних комплексів, до яких вони належать.

Також варто зазначити, що для створення геопарку потрібні не тільки ідеї, дослідницька діяльність та вирішення важливих проблем, а й злагоджена співпраця всіх зацікавлених осіб та організацій, у тому числі держави та місцевого населення. Звісно, у разі порушення цього питання в Україні також виникає проблема фінансування, в першу чергу це державні кошти. Але ж організатори можуть подати запити на фінансування проекту до міжнародних фондів.

Простеживши розвиток шляху до створення геопарків в Україні, пропонуємо розглянути найбільш цінні геологічні об’єкти, як кандидати на роль перспективних національних геопарків (Manyuk, 2006). (Деякі з них уже були названі: Подільські Товтри, Бузький Гард та геосайт «Орлине гніздо»).

1. Стильське відслонення. На значній відстані узбережжя р. Мокра Волноваха, від с. Миколаївка до с. Стила і далі, як по лівому, так і по правому їі берегах, мальовничо відслонюється в усьому його різноманітті розріз верхньодевонських та кам'яновугільних відкладів. Річка перетинає Південно-Донецький та Стильський грабени. Прямуючи від с. Миколаївка, можна послідовно спостерігати породи докембрію (габро із прожилками аплітових рожевих гранітів), аркозові пісковики та осадово-вулканогенні утвори девону, що складають своєрідні горбисті форми рельєфу, сірі міцні вапняки турнейського ярусу нижнього карбону з відбитками Spirifer sp., Atrypa sp. та інші. Покривні базальти та дайко-екструзивні тіла входять до складу спіліто-кератофірової формації і характеризуються значним різноманіттям складу. Цей геологічний об’єкт - кращий відкритий розріз теригенно-вулканогенних відкладів верхнього девону i нижнього карбону, у відслоненнях якого багато решток викопних рослин і тварин.

2. Зачарована долина (Смереків камінь). Геологічний заказник місцевого значення площею 150 гектарів, який відзначається своєрідними рідкісними формами скельного рельєфу. У результаті водноповітряної ерозії виникли оригінальні кам'яні утвори висотою до 100 м. Заказник розташований в межах національного природного парку «Зачарований край» на території Іршавського району Закарпатської області. Створення геопарку на цій території тільки поліпшить умови збереження цінних об'єктів та організації туризму.

3. Гранітний масив «Кам'яні могили», що знаходиться на території степового заповідника, розташованого в басейні р. Каратиш, в Куйбишевському районі Запорізької області. Унікальне природне творіння у вигляді скельних горбів останців, які підвищуються над рівнем річки на 100 - 110 м. Скельні пасма складені переважно рожевими крупнозернистими порфіроподібними біотитовими гранітами кам'яномогильського комплексу середнього протерозою. Цей район має не тільки геологічну цінність, а й велику біологічну та історико-археологічну цінність. Оскільки з кожним роком зацікавленість туристів до цього місця зростає все більше, є підстави говорити про створення геопарку на цій території.

4. Висачківський соляний купол. Це геологічна пам'ятка природи місцевого значення, розташована в Полтавській області. Висачківська структура 
відбита в рельєфі горбом, витягненим у північнозахідному напрямку. Потужним соляним штоком девонського віку на поверхню винесені брили базальтів, туфобазальтів, діабазів, туфобрекчій та долеритів разом із вапняками та гіпсом. Після тривалої експлуатації пагорба 3 діабазовим ядром на його місці виникло озеро зі скелястими берегами. Але, на жаль, на сьогодні воно перетворюється на смітник, де головним компонентом сучасного пейзажу стали пластикові пляшки. Це місце навіть не має таблички з означенням території пам'ятки природи. Тому цей геологічний об'єкт потребує захисту і одним iз можливих вирішень проблеми є саме створення геопарку державного значення.

5. Гляціотектоніка гори Пивиха в Полтавській області - одне з яскравіших свідчень руйнівної роботи Дніпровського материкового зледеніння. Внаслідок гляціодислокацій льодовиком деформовані і переміщені велетенські масиви палеогенових порід і насунуті на породи четвертинної системи. Це явище можна спостерігати у стрімких кручах Дніпра поблизу села Градизьк. У відслоненнях г. Пивиха присутні: мергель (у тому числі і блакитний), глина, пісок, кристалічний гіпс. В обривах пагорба вчені знаходять скам'янілі залишки рослин і тварин льодовикового періоду. Після зведення в кінці 1960-х рр. Кременчуцького водосховища Пивиха поступово руйнується. Щорік вода поглинає близько 7 м гори. Також загроза для цього геологічного об'єкта надходить від антропогенних факторів с. Градизьк.

6. Базальтові стовпи «Іванова долина». Заказник на Рівненщині є комплексним: стратиграфічний, петрографічний, мінералогічний, палеовулканічний, де відкриті базальти верхнього протерозою з досконалими окремими класичними стовпами. Загальна протяжність відслонень базальтів у межах заказника 180 - 230 м. Висота ідеальних шестигранних стовпів досягає 30 м. Крім того, також можна спостерігати округлі базальтові стовпи $з$ діаметром до 0,5 м. У розкритті кар'єру базальтові породи мають і різноманітний вибір мінералів: джеспероїди, гірський кришталь, аметист, агат, анальним, самородна мідь та інші.

7. Канівські гляціодислокації. Канівські гори являють собою гляціотектонічні утвори в 7 км від Канева в межах території Канівського природного заповідника. У момент Дніпровського зледеніння тут були інтенсивно дислоковані породи з тріасу до раннього четвертинного віку, після чого був сформований досить своєрідний рельєф. Такий геологічний об'єкт настільки унікальний та мальовничий на теренах України, що дає підстави для створення геопарку державного значення.
Висновок. Ідея створення мережі геологічних парків в Україні розвивається 3 90-х років минулого століття, але жодного парку ще не створено. Українські вчені-геологи ретельно працюють над цим питанням і вже досягли деяких позитивних результатів. Так, це наукові публікації з переліком геологічних об'єктів, що можуть бути віднесені до геопарків, $з$ детальними планами для створення парків, 3 розглядом проблем та їх вирішенням. Створення геопарків потребує важкої роботи, вже не говорячи про постійне фінансування в немалих розмірах. Це й детальне опрацювання і розробка поетапного плану їх функціонування, й вжиття низки організаційних, освітніх, інженерно-технічних заходів. Але результат такої роботи буде вартий проробленого шляху. Адже геопарки створюють перспективи для охорони регіональних цінностей геологічної спадщини у поєднанні з їх популяризацією. Також вони дають кращі можливості для розвитку туризму та геоосвіти, ніж усі інші види природоохоронних установ. Парки потрібні для збереження історико-культурних цінностей та сталого розвитку приро-доохоронних територій.

Україна - країна з унікальним геологічним $\mathrm{i}$ природним розмаїттям, гідна мати у складі свого природно-заповідного фонду хоча б один національний геологічний парк.

\section{Бібліографічні посилання}

Barbot-de-Marni, E.N. 1872. Geologicheskie issledovanija, proizvedennye v 1868 godu v gubernii Kievskoj, Podol'skoj i Volynskoj [Geological studies in the province of Kiev, Podolia and Volyn in 1868]. Notes of the mineralogical society. St. Petersburg, №8 (in Russian).

Bezvynniy, V.P., Bileckij, S.V.\& Bobrov, O.B. 2006. Geologichni pam'jatky Ukrai'ny [Geological landmarks of Ukraine]. Kyiv, 4, 205-260 (in Ukrainian \& English).

Golturenko, I.P., Manyuk, V.V., \& Artamonov, V.A. 2011 Geologichnyj park Mykolai’vshhyny [Geological Park of Mykolayiv]. The collection of materials of II international scientific-practical conference. Kyiv, Logos, 30-33 (in Ukrainian).

Ivchenko, A.S. 1998. Geologichna spadshhyna Ukrai'ny: suchasnyj stan pytannja [Geological Heritage of Ukraine: studying international experience]. Geography and economic fundamentals in school. Kyiv, Educational Media, №3, 6-7 (in Ukrainian)

Kaplun, I.H., Chebolda I.Y. 2008. Geopark jak model' zberezhennja ta optymal'nogo pryrodokorystuvannja podil's'kyh tovtr [Geopark as a model of conservation and management of natural resources Podil'ski Tovtry]. Materials of international scientific-practical conference "Protection and management of objects of inanimate nature 
in protected areas". Hrymailiv, 121-126 (in Ukrainian). Korolyuk, I.K. 1952. Podol'skie Toltry i uslovija ih obrazovanija [Podil'ski Tovtry and conditions of their formation]. Proceedings of the Institute of Geology. Moscow, USSR Academy of Sciences, №56, 140 (in Russian).

Manyuk, V.V. 2008. Istorychni peredumovy stvorennja nacional'nogo geologichnogo parku "Orlyne gnizdo" [Historical preconditions building national geological park "Eagle's Nest"]. Materials of international scientificpractical conference "Protection and management of objects of inanimate nature in protected areas". Hrymailiv, 175 - 181 (in Ukrainian).

Manyuk, V.V. 2014. Novyj navchal'nyj kurs dlja studentiv geologichnyh special'nostej [New course of study for students of geological specialties]. Materials of international scientific conference "The role of higher education institutions in the development of Geology". Kyiv, 22-23 (in Ukrainian).

Manyuk, V.V. 2006. Potential objects for creation of a Network National Geoparks in Ukraine. ProGEO Symposium "Safeguarding our Geological Heritage". Kyiv-KamianetsPodil'sky, 30-32.

UNESKO Geoparks Programme - a new initiative to promote a global network of geoparks safeguarding and developing selected areas having significant geological features. 1999. Hundred and fifty-sixth Session. United Nations Educational, Scientifical and Culturel Organization: Executive Board. Paris, 1-4. 